\title{
Environmental Health Threats Associated with Drainage from a Coastal Urban Watershed
}

\author{
Charles Humphrey ${ }^{1}$, Jamil Blackmon ${ }^{1}$, Tim Kelley ${ }^{1}$, Michael O'Driscoll ${ }^{1} \&$ Guy Iverson ${ }^{1}$ \\ ${ }^{1}$ East Carolina University, United States \\ Correspondence: Charles Humphrey, East Carolina University, United States. E-mail: Humphreyc@ecu.edu
}

Received: December 22, 2017

Accepted: January 10, $2018 \quad$ Online Published: January 22, 2018

doi:10.5539/enrr.v8n1p52

URL: https://doi.org/10.5539/enrr.v8n1p52

\begin{abstract}
The project goal was to determine if stormwater runoff and the legacy effects of leaking underground storage tanks (UST) posed an environmental health threat along an urban stream, Town Creek (TC). Baseflow and stormflow samples were collected from TC between March and October 2016 for physical and chemical characterization and E. coli analyses. Groundwater seeps and wells near the banks of TC were also sampled for $E$. coli and benzene analyses. Stormflow concentrations of $E$. coli were significantly $(\mathrm{p}<0.05)$ elevated relative to preceding baseflow and groundwater concentrations. Overall, $80 \%$ of stormflow samples and $45 \%$ of baseflow samples exceeded the US EPA recommended standards for $E$. coli in recreational waters. Benzene was detected in all water samples analyzed and $50 \%$ of samples collected from a seep on the western bank of TC exceeded the maximum contaminant level. Concentrations of benzene emitted to air from contaminated soil exceeded short term exposure standards $75 \%$ of times sampled. Results suggest the drainage from TC may be a threat to environmental health. Implementation of stormwater control measures is suggested to reduce the delivery of runoff and E. coli to TC. Remediation of groundwater contaminated by leaking underground storage tanks is also suggested.
\end{abstract}

Keywords: benzene, environmental health, fecal bacteria, stormwater, underground storage tanks

\section{Introduction}

\subsection{Town Creek and Urban Runoff}

Town Creek (TC) drains a $\sim 1 \mathrm{~km}^{2}$ urbanized section of the City of Greenville in the Coastal Plain of North Carolina (NC), and is a tributary to the Tar River (Figure 1). The TC watershed is predominantly covered (66\%) with impervious surface (IS) and runoff is routed to storm drains and storm sewers that are connected to TC. The main channel of TC has been piped and buried, and TC "daylights" approximately $350 \mathrm{~m}$ upstream from the Tar River (Figure 1). The TC watershed receives an average of $126 \mathrm{~cm}$ of precipitation per year with monthly means varying from $7.9 \mathrm{~cm}$ in November to $15.6 \mathrm{~cm}$ in August (US Climate Data, 2017). The summer months of June to September receive on average $55 \mathrm{~cm}$ of rainfall, while winter months (December to March) typically receive $37 \mathrm{~cm}$. Temperatures are typically coldest during the winter months when mean daily temperatures range between $2.4{ }^{\circ} \mathrm{C}$ and $9{ }^{\circ} \mathrm{C}$. The summer months have the highest mean daily temperatures $\left(24.8^{\circ} \mathrm{C}\right.$ to $\left.28.1{ }^{\circ} \mathrm{C}\right)$. Average rainfall in the summer ranges between $10.9 \mathrm{~cm}$ to $15.6 \mathrm{~cm}$ per month. The runoff associated with the abundant rainfall and IS may influence the water quality of TC and the health of people that recreate in those waters. At the mouth of TC is Town Commons, a major recreational area frequented by citizens whom utilize the water resources for kayaking, fishing and other activities. When urbanization occurs and the land is covered with IS (roads, parking lots, roof tops), rainwater infiltration decreases and runoff increases (Whitlock et al., 2002; Iverson et al., 2017). Pollutants including pathogens from animal waste that collect on hard surfaces may be transported via runoff to storm sewers and eventually receiving waters (Smith \& Perdek, 2004). Prior studies (Mallin et al., 2000; Humphrey et al., 2015; Iverson et al., 2017) have shown that as the percentage of IS increases in a watershed, runoff volumes and pollutant loads increase significantly during rain events, causing water quality degradation. Stormwater runoff is one of the most common factors related to water use impairment (Mallin et al., 2000). Considering the typical rainfall patterns, IS and storm sewer networks in the TC watershed, urban runoff may transport microbial pathogens to recreational waters near Town Commons, thus endangering public and environmental health. 


\subsection{Urban Runoff and Fecal Indicator Bacteria}

There are many different pathogens in fecal waste including viruses, bacteria, and protozoa that can cause illness and sometimes death (US CDC, 2017a) if these pathogens are delivered in high concentrations to water resources. For example, each year over 500,000 people die because of diarrhea associated with consumption of fecal-contaminated water (WHO, 2017). Testing recreational waters for each potential pathogen in waste material would be time consuming and very expensive. The US EPA (1986) suggests using the fecal indicator bacteria (FIB) E. coli for assessing the potential health threats associated with pathogens because significant correlations were observed between $E$. coli concentrations in recreational waters and rates of human illness for people using the waters. The single-sample threshold for E. coli concentrations in freshwaters is $235 \mathrm{cfu} 100$ $\mathrm{mL}^{-1}$, therefore when concentrations of $E$. coli exceed that value, the health threats of recreational contact with the water are considered high (US EPA, 1986). Forty percent of rivers and estuaries in the US have concentrations of FIB that exceed the recommended thresholds, and urban runoff is a major contributor of FIB to those waters (Smith \& Perdek, 2004). Concentrations of FIB in surface waters are typically highest during storm events and warm seasons (Smith and Perdek, 2004; Hathaway et al., 2010; Iverson et al., 2017). Warm months are when water-based recreation is most likely to occur, coinciding with periods when FIB concentrations are typically the highest, potentially compromising environmental health. Concentrations of FIB in surface waters may also be influenced by groundwater transport of FIB from non-point sources such as septic tank effluent discharged to the subsurface (Humphrey et al., 2015; Iverson et al., 2017). Therefore, monitoring groundwater and surface water is suggested with regards to determining sources of FIB pollution in streams (Humphrey et al., 2015) and developing remediation strategies.

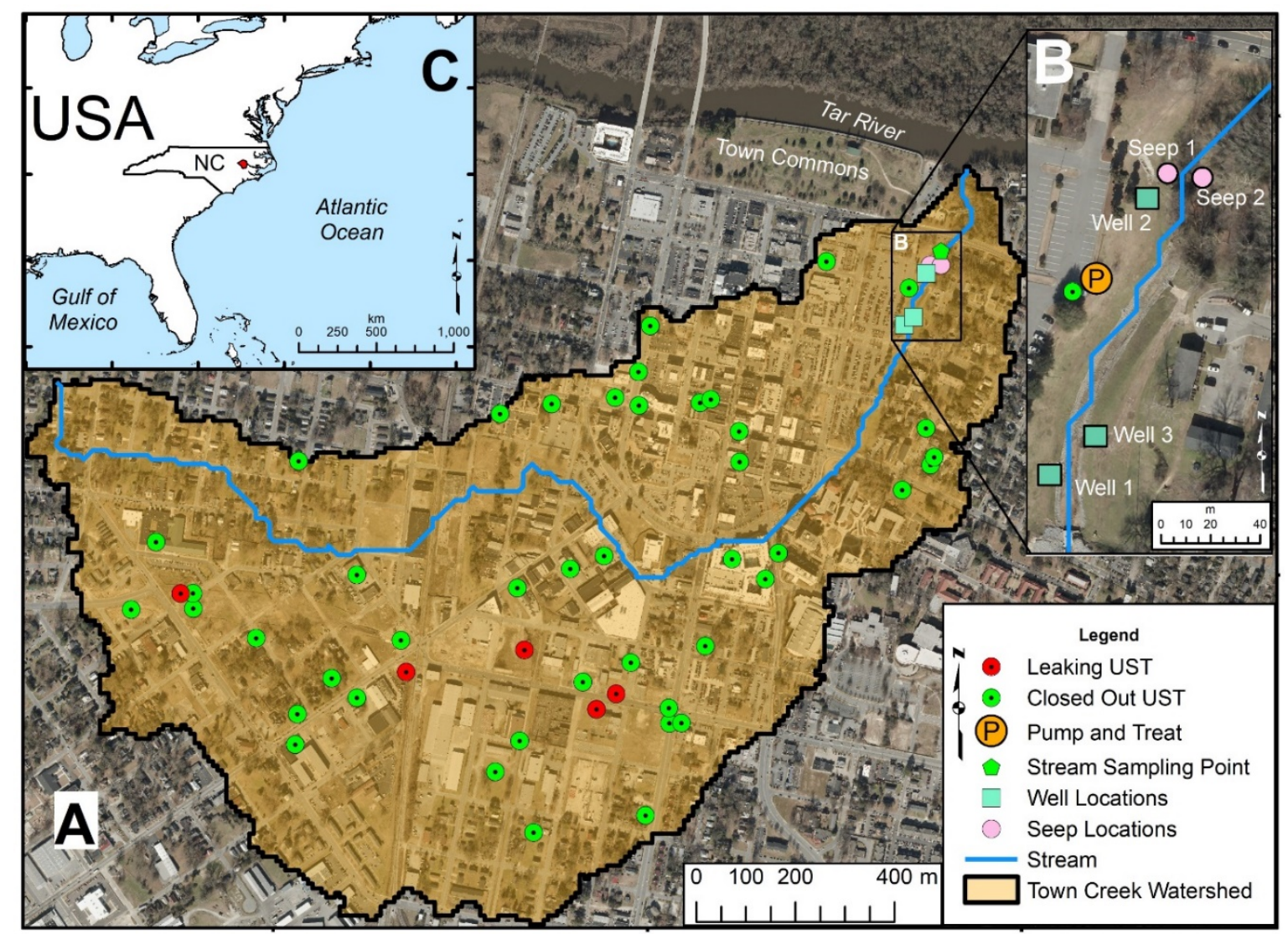

Figure 1. Town Creek watershed (A) with sampling locations (B) in Greenville North Carolina (C). Location B is where the creek "daylights". Upstream from B, the creek is piped and buried. Location of pump and treat system is approximate. Greenville, North Carolina is on the east coast of the United States of America (C) 


\subsection{Leaking Underground Storage Tanks and Benzene}

In addition to urban runoff issues, complaints regarding gasoline odors and oily sheens on the water at TC have occurred since the 1980's (NC DEQ, 2017). A gasoline spill was reported in April 1986 and later investigations suggested that several underground storage tanks (UST) were leaking within the TC watershed, contaminating groundwater, and that petroleum-contaminated groundwater was discharging to the lower reaches of TC (S\&ME, 2011). The North Carolina Department of Environmental Quality (NC DEQ) spearheaded efforts to remove or abandon leaking UST located to the north and west of the main channel of TC. Then, a pump and treat system was implemented in 1991 adjacent to the creek to improve water quality (Figure 1). The system pumped and treated approximately 23 million liters of contaminated groundwater. Pump and treat efforts were discontinued after only a few years due to a change in policy (Senate Bill 1317), and the designation of the waters of TC as "low priority". As a result, no remediation has occurred since the mid 1990's (S\&ME, 2011). However, "gasoline odors" and "oily substances" along the western banks of TC near Town Commons still persist even though the case was considered closed by regulatory officials.

The issues related to leaking UST are not isolated to TC. There are over 6,300 known fuel releases from UST in the state of NC, over 580,000 in the US (US EPA, 2011), and urban areas in many other countries face similar issues (Calza et al., 2015). In the NC coastal region, approximately $89 \%$ of the open UST leakage cases show contamination to groundwater (US EPA, 2011). UST are considered one of the greatest environmental threats, due to the number of UST, the toxic substances such as benzene that they contain, and their potential for leaking and contaminating groundwater and surface water (US EPA, 2011). Benzene is a constituent in fuel and a carcinogen linked with various types of lymphoma, leukemia, and blood diseases (Yang et al., 2013). Benzene is prone to leaching through soils into groundwater (Meszaros et al., 2017) and may persist and be transported with groundwater for extended periods and distances (Haest et al., 2010; Calza et al., 2015). The maximum contaminant level (MCL) for benzene in US drinking water supplies is $5 \mu \mathrm{g} \mathrm{L}^{-1}$ (US EPA, 2017b). Exposure to benzene may also occur via direct contact by swimming or wading in contaminated surface water (US CDC, 2017) or through inhalation (Gallagos et al., 2007; Abou-Shanab et al., 2016). The recreational water threshold concentration for benzene is $51 \mathrm{\mu g} \mathrm{L}^{-1}$ (US EPA 2017b). When concentrations exceed this standard, people swimming or wading in the water may be at risk due to exposure to the carcinogen. Permissible atmospheric

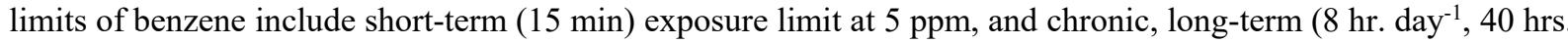
week $^{-1}$ ) exposure limit at $1 \mathrm{ppm}$ (ATSDR, 2016). When concentrations of benzene in the air reach between 1.5 and $5 \mathrm{ppm}$, the odor becomes apparent (ATSDR, 2016). Therefore, if benzene odors are noticeable, there may be negative health risks associated with inhalation of the vapors for extended periods.

\subsection{Project Goal and Objectives}

The goal of this project was to determine if legacies of urban land use affected water quality and air quality in a way that could pose environmental and public health threats. Specific objectives were to determine if concentrations of E. coli in TC during baseflow and stormflow exceeded the EPA (1986) suggested single-sample threshold for recreational waters $(235 \mathrm{cfu} / 100 \mathrm{~mL})$ and if benzene was present in water, soil and air along the banks of TC in concentrations that exceeded regulatory standards.

\section{Methods}

\subsection{Stream Sampling and Biochemical Analyses}

TC was sampled 1 to 2 times per month during base flow conditions between March and October of 2016 ( $\mathrm{n}=$ $11)$ to determine the concentrations of $E$. coli. Storm flow samples from TC were also collected and analyzed for E. coli on 5 occasions. Project investigators monitored the weather forecast and when a rain event was predicted for a given day, investigators sampled TC during baseflow just prior to rain. Samples were also collected from TC later the same day and during rainfall and the rising limb of the hydrograph. Baseflow and stormflow concentrations of $E$. coli were compared. Overall, TC was sampled 16 times for $E$. coli analyses. The physical and chemical properties of water were measured using an YSI 556 multi-meter probe system on each sampling date. The measured parameters included $\mathrm{pH}$, dissolved oxygen, temperature, specific conductance, and oxidation reduction potential, and flow. Stream velocity was measured using a Global Water model FP111 flow meter. The active cross-sectional area of the stream $\left(\mathrm{m}^{2}\right)$ was measured and used along with the velocity data $\left(\mathrm{m} \mathrm{s}^{-1}\right)$ to determine stream discharge $\left(\mathrm{L} \mathrm{s}^{-1}\right)$. Turbidity was measured using a Hach 2100P Turbidimeter 46500-00. Water samples were collected using sterile bottles that were placed in ice-filled coolers for sample preservation. Water samples were prepared for E. coli analyses within 6 hours of collection at the Environmental Health Sciences Water Lab at East Carolina University. Samples were analyzed for $E$. coli using the $I D E X X$ Colilert $^{\circledR}$ media with Quanti-Tray 2000 methods. 


\subsection{Groundwater Sampling and Biochemical Analyses}

Groundwater discharge samples were collected approximately bi-monthly $(\mathrm{n}=8)$ between March and September 2016 (spring and summer) near "seeps" along the western bank (Seep 1) and eastern bank (Seep 2) of TC (Figure 1). Discharge from the seeps flow into TC and may influence water quality of TC and the Tar River, where water-based recreation occurs. The spring and summer are the periods when people are more likely to engage in water-based recreation and when exposure to water contaminants may be highest, thus this time frame served as the study period. Water samples were also collected from three existing groundwater wells adjacent to TC 8 times during the study for physical and chemical characterization and E. coli analyses. Two wells were on the west side of TC (Well 1 and 2) and one well on the east side (Well 3) (Figure 1). The wells were installed with 1 $\mathrm{m}$ screen intervals, and at similar depths $(3.7$ to $4.3 \mathrm{~m})$ in the surficial aquifer. A Solinst meter was used to determine the depth to groundwater, as well as temperature, level and conductivity from each well. Groundwater samples were collected from each well using a new disposable bailer. The wells were purged prior to sample collection. The physical and chemical properties of water discharging from the seeps and in the wells were measured in the field during sample collection using an YSI 556 multi-meter probe system. During 5 events, water samples near Seep $1(\mathrm{n}=4$ seep samples; $\mathrm{n}=1 \mathrm{TC}$ sample) were collected in glass bottles with 0 headspace and analyzed for benzene concentrations at Environment 1, a private water quality lab in Greenville, NC. A water sample from Well 2 was also collected and analyzed for benzene with a Hewlett-Packard 5890 Series II Gas Chromatograph with OI Photo Ionization Detector and Tekmar Purge \& Trap Concentrator with EPA's Method 602. Funding for this study limited the number of water samples that could be collected and analyzed for benzene. However, a report by S\&ME (2011) included benzene sampling results $(n=4)$ from Seep 1 , and data from their report and this study were synthesized to allow for eight measurements from that sampling location. Benzene concentrations in the water samples were compared to the maximum contaminant level (MCL) of $51 \mu \mathrm{g} \mathrm{L}^{-1}$ to determine if the concentrations posed public and environmental health threats. The frequency of MCL exceedance was reported. Discharge $\left(\mathrm{L} \mathrm{s}^{-1}\right)$ from the seep was estimated by placing a graduated cylinder in a channel extending from the seep, and using a stop watch to record the time needed to fill the cylinder. Benzene loading $\left(\mathrm{mg} \mathrm{d}^{-1}\right)$ was calculated by multiplying the seep discharge by benzene concentration.

\subsection{Soil Sampling and Air Quality Analyses}

Soil samples ( $\mathrm{n}=4$ for each location) were collected by hand from Seep 1 and Seep 2 adjacent to TC. Approximately $500 \mathrm{~cm}^{3}$ of soil from the upper $10 \mathrm{~cm}$ of the profile was placed in a zip-lock bag and sealed for each location during each event. The bags were placed in direct sunlight for 0.5 hours and then the portable MiniRAE $2000^{\circledR}$ VOC Monitor PGM - 7600 was used to determine the concentrations of benzene (ppm) emitted from the soil (Operation and Maintenance Manual, 2005). The benzene concentrations emitted from soil collected on each side of the creek were compared to each other and to the air quality standards to determine if the soil was contaminated with benzene and if the concentrations emitted were high enough to pose a public health threat.

\section{Results and Discussion}

\subsection{Baseflow and Stormflow E. coli Concentrations}

Concentrations of $E$. coli in TC were variable and frequently elevated relative to the EPA suggested threshold of $235 \mathrm{MPN} 100 \mathrm{~mL}^{-1}$ (Figure 2). Overall, 5 of 11 baseflow (45\%), 4 of 5 stormflow (80\%) and thus $56 \%$ (9 of 16) of all samples collected from TC exceeded the recommended threshold. Concentrations of $E$. coli increased during all 5 storm flow events in comparison to preceding base flow conditions (Figure 2) and the differences in concentrations were significant $(\mathrm{p}=0.034)$. Prior research in urban/urbanizing watersheds of eastern $\mathrm{NC}$ has also shown increases in concentrations of $E$. coli in streams during stormflow relative to baseflow conditions (Hathaway et al., 2010; Humphrey et al., 2015; Iverson et al., 2017) and frequent exceedance of water quality standards. Baseflow is sustained by groundwater discharge, and thus groundwater E. coli concentrations may influence E. coli concentrations of streams especially between rain events (Humphrey et al., 2015; Iverson et al., 2017). However, geometric mean concentrations of $E$. coli were lower in groundwater from Wells 1-3 (16 to 229 MPN $100 \mathrm{~mL}^{-1}$ ) and in TC during baseflow (geometric mean: $126 \mathrm{MPN} 100 \mathrm{~mL}^{-1}$ ) relative to stormflow concentrations (639 MPN $100 \mathrm{ml}^{-1}$ ) (Table 1), and the differences were statistically significant $(\mathrm{p}<0.05)$. These findings suggest that urban runoff is a major mechanism for $E$. coli transport and delivery to TC during rain events and concentrations of $E$. coli in TC during storms are more related to runoff rather than groundwater discharge. Statistically significant differences in concentrations of $E$. coli were not observed when comparing samples collected from Seep 1 and 2 to stormflow concentrations in TC. Residents of nearby apartments were seen walking dogs along the creek, and water fowl and cats were frequently observed near the Seeps. Because water samples from the Seeps were collected at the soil surface, the samples may have been exposed directly to 
pet and wildlife waste, thus influencing the concentrations of $E$. coli in the samples. Research by Wright et al. (2009) in coastal Florida and Ahmed et al (2006) in Queensland Australia also reported that pets such as dogs may be dominant sources of fecal indicator bacteria to soil and/or surface waters. The results of this study indicate that $E$. coli concentrations commonly exceed the water quality standards during baseflow and stormflow, and drainage from TC may be a threat to public and environmental health via exposure to recreational waters with elevated $E$. coli concentrations.

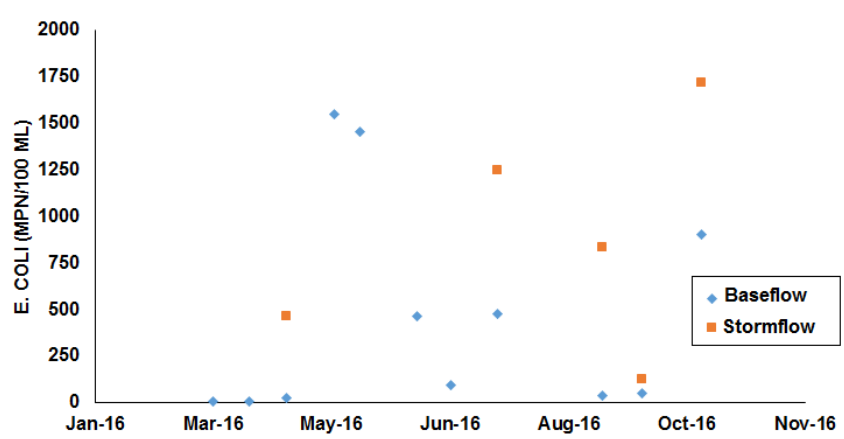

Figure 2. Concentrations of E. coli during baseflow and stormflow conditions

\subsection{Baseflow and Stormflow Physical and Chemical Properties}

During storm events, there were increases in flow, turbidity, oxidation-reduction potential and temperature of surface waters relative to preceding baseflow conditions (Table 1). On average, the measured discharge during base flow was $5.4 \pm 3.0 \mathrm{~L} \mathrm{~s}^{-1}$ and storm flow was $28.8 \pm 4.5 \mathrm{~L} \mathrm{~s}^{-1}$, and the differences were significant at $\mathrm{p}=$ 0.002. Given the high percentage of IS within the TC watershed, significant differences in stormflow relative to baseflow were expected. The average turbidity during base flow was $10.7 \pm 12.4$ NTU, while the average turbidity during storm flow $(169.3 \pm 56.9 \mathrm{NTU})$ was significantly $(\mathrm{p}=0.007)$ higher (Table 1$)$. This could be explained by the increase of sediment in surface water during storm flow compared to base flow. The average ORP during base flow was $(-148 \pm 70 \mathrm{mV})$ while the storm flow average was $(-44 \pm 65 \mathrm{mV})$ (Table 1). The differences in oxidation-reduction potential were significant at $\mathrm{p}=0.002$ and the greater ORP during storms may have been related to turbulent flow across the large stones lining the creek. Temperatures increased in TC during stormflow may have been related to runoff from warm asphalt and rooftops within the highly impervious (66\%) watershed. The rainfall received during the study period $(115 \mathrm{~cm})$ was elevated relative to the long-term average $(84 \mathrm{~cm})$ with most of the excess occurring in June $(+15 \mathrm{~cm})$ and September $(+15.6 \mathrm{~cm})$ of 2016 (US Climate Data, 2017). The other months more closely matched the long-term averages for precipitation. Mean daily temperatures were between $15^{\circ} \mathrm{C}$ in March to $28^{\circ} \mathrm{C}$ in July and August, and were similar to the long term averages $\left(9^{\circ} \mathrm{C}\right.$ to $\left.28^{\circ} \mathrm{C}\right)$ (US Climate Data, 2017).

\subsection{Benzene Concentrations in Water Resources}

Benzene was detected in all water samples collected from Seep $1(\mathrm{n}=4)$, TC $(\mathrm{n}=1)$ and in groundwater collected from monitoring Well $2(\mathrm{n}=1)$ during this study. Sampling was initiated in March, when Seep 1 was submerged with flood water from TC. The benzene concentration near Seep 1 was lowest in March $\left(12.55 \mu \mathrm{g} \mathrm{L}^{-1}\right)$, most likely because of dilution from floodwaters. Concentrations of benzene from Seep 1 were $37.05 \mu \mathrm{g} \mathrm{L}^{-1}$ in April and 31.6 $\mu \mathrm{g} \mathrm{L}{ }^{-1}$ in May. The June and September sampling events yielded benzene concentrations of $78.5 \mu \mathrm{g} \mathrm{L}^{-1}$ and $73.6 \mu \mathrm{g}$ $\mathrm{L}^{-1}$, respectively, which exceeded the standard of $51 \mu \mathrm{g} \mathrm{L} \mathrm{L}^{-1}$. The April through September samples were collected during lower stream stage periods when Seep 1 was not inundated (and diluted) with TC flood waters. Overall, 50\% of samples ( 2 of 4 ) collected from Seep 1 exceeded the MCL during this study period. Benzene data from Seep 1 sampled prior to this study (S\&ME, 2011) also showed 50\% (2 of 4) of samples exceeded the standard. Therefore, 4 of the last 8 samples (50\%) collected from Seep 1 have exceeded the MCL (Figure 3). Groundwater sampled from Well 2 (up-gradient from Seep 1) in May had a concentration of benzene $\left(28.7 \mu \mathrm{g} \mathrm{\textrm {L } ^ { - 1 } )}\right.$ similar to concentrations observed at Seep 1 during the same time frame $\left(31.6 \mu \mathrm{g} \mathrm{L}^{-1}\right.$ in April). The mass-loading rate of Benzene to TC was between $3.5 \mathrm{mg} \mathrm{day}^{-1}$ to $27.7 \mathrm{mg} \mathrm{day}^{-1}$, with an average of $16.3 \mathrm{mg} \mathrm{day}^{-1}$. At this average rate, $5.9 \mathrm{~g} \mathrm{yr}^{-1}$ of benzene would be discharged into Town Creek from the Seep. The discharge from Seep 1 was typically less than $1 \%$ of the discharge for TC, thus dilution likely influences concentrations of benzene in TC and the Tar River, as shown during the initial sampling event. The expected dilution of benzene contaminated groundwater with surface water may have been a factor in TC being listed as "low priority" site. 
Table 1. Mean and standard deviation of physical and chemical parameters of Town Creek during baseflow immediately prior to stormflow conditions (P). Characteristics of all baseflow samples denoted by (A)

\begin{tabular}{|c|c|c|c|c|c|c|c|}
\hline $\begin{array}{l}\text { Sampling } \\
\text { Conditions }\end{array}$ & $\begin{array}{c}\text { Specific } \\
\text { Conductance }(\mu \mathrm{S} \\
\left.\mathrm{cm}^{-1}\right)\end{array}$ & $\begin{array}{c}\text { Oxidation } \\
\text { Reduction Potential } \\
(\mathrm{mV})\end{array}$ & $\mathrm{pH}$ & $\begin{array}{c}\text { Temperature } \\
\left({ }^{\circ} \mathrm{C}\right)\end{array}$ & $\begin{array}{c}\text { Turbidity } \\
\text { (NTU) }\end{array}$ & $\begin{array}{l}\text { Flow } \\
\left(\mathrm{L} \mathrm{s}^{-1}\right)\end{array}$ & $\begin{array}{c}\text { E. coli (MPN } \\
\left.100 \mathrm{~mL}^{-1}\right)\end{array}$ \\
\hline Baseflow (P) & $308(62)$ & $-148(70)$ & $7.4(0.3)$ & $24.0(2.0)$ & $10.7(12.4)$ & $5.4(3.0)$ & $117(388)$ \\
\hline Stormflow & $212(57)$ & $-44(65)$ & $7.0(0.8)$ & $25.1(1.6)$ & $169.3(56.9)$ & $28.8(4.5)$ & $639(628)$ \\
\hline Baseflow (A) & $339(42)$ & $-86(54)$ & $7.2(0.3)$ & $19.4(3.1)$ & $5.8(4.5)$ & $3.5(2.2)$ & $126(587)$ \\
\hline
\end{tabular}

\subsection{Benzene in Soil and Air}

Soil samples were collected four times during the study from Seep 1 and Seep 2 to determine the potential concentration of benzene released into the air from the soil. The values measured during the study were variable but always higher near Seep 1 relative to Seep 2 (Figure 4). All but one of the samples collected near Seep 1 exceeded the short-term exposure (15-minute) level of $5 \mathrm{ppm}$ and all samples exceeded the chronic exposure level of $1 \mathrm{ppm}$ (US CDC, 2017), providing evidence that benzene contamination of groundwater, and groundwater contamination of soil still occurs. The average concentration of benzene emitted from soil near Seep 1 was $28.13 \mathrm{ppm}$, more than five greater than the short-term exposure threshold. Strong fuel odors were present during each field visit $(n=16)$. Repeated exposure at the concentration levels observed during the study could have detrimental health effects on visitors. Environmental readings also suggest that groundwater, particularly on the west side of TC was influenced by leaking UST. For example, the dissolved oxygen concentrations and oxidation reduction potentials were significantly $(\mathrm{p}<0.05)$ lower in water discharged from Seep $1\left(3.4 \pm 3.3 \mathrm{mg} \mathrm{L}^{-1} ;-193 \pm 90 \mathrm{mV}\right)$ relative to Seep $2\left(6.8 \pm 1.4 \mathrm{mg} \mathrm{L}^{-1} ;-97 \pm 63 \mathrm{mV}\right)$ (Table 2).

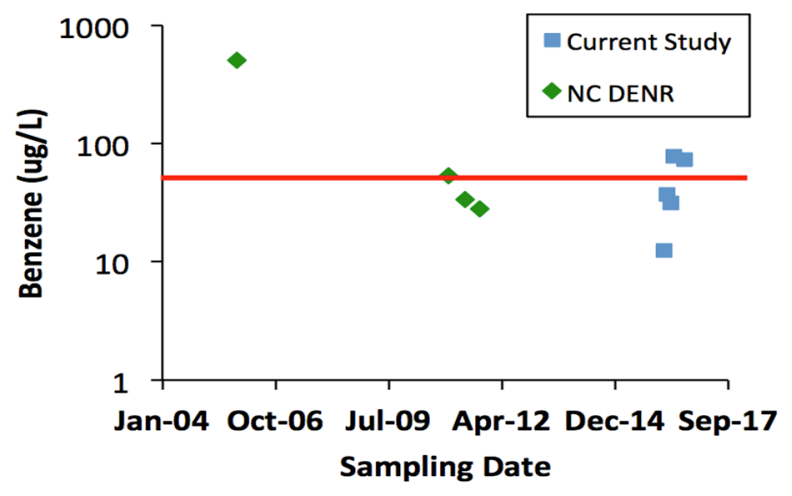

Figure 3. Benzene concentrations in water near Seep 1 as reported by NC DENR (green squares) and during this study (blue squares). Red line indicates the $51 \mu \mathrm{g} / \mathrm{L}$ standard for recreational contact

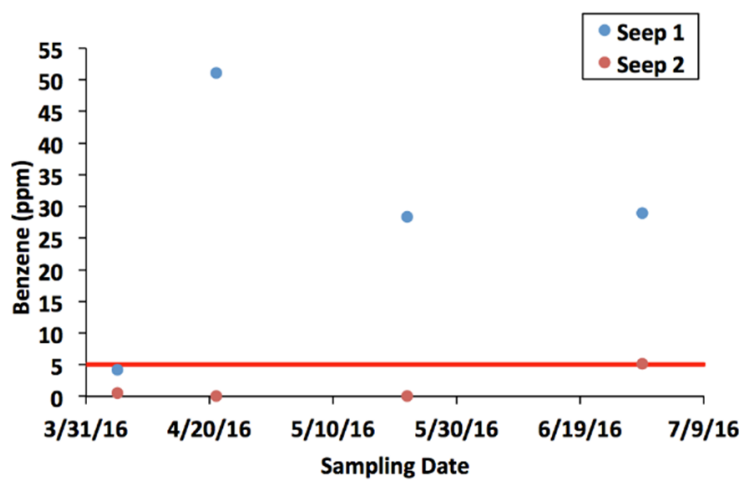

Figure 4. Benzene concentrations emitted to the air from soil collected near Seep 1 and Seep 2. Red line indicates the 5-ppm short-term exposure standard

Table 2. Mean and standard deviation of physical, chemical, and biological parameters of water collected from locations on the west side of Town Creek, (Seep 1, Well 1 and Well 2) and the east side (Seep 2, Well 3). Geometric mean of E. coli and standard deviation reported.

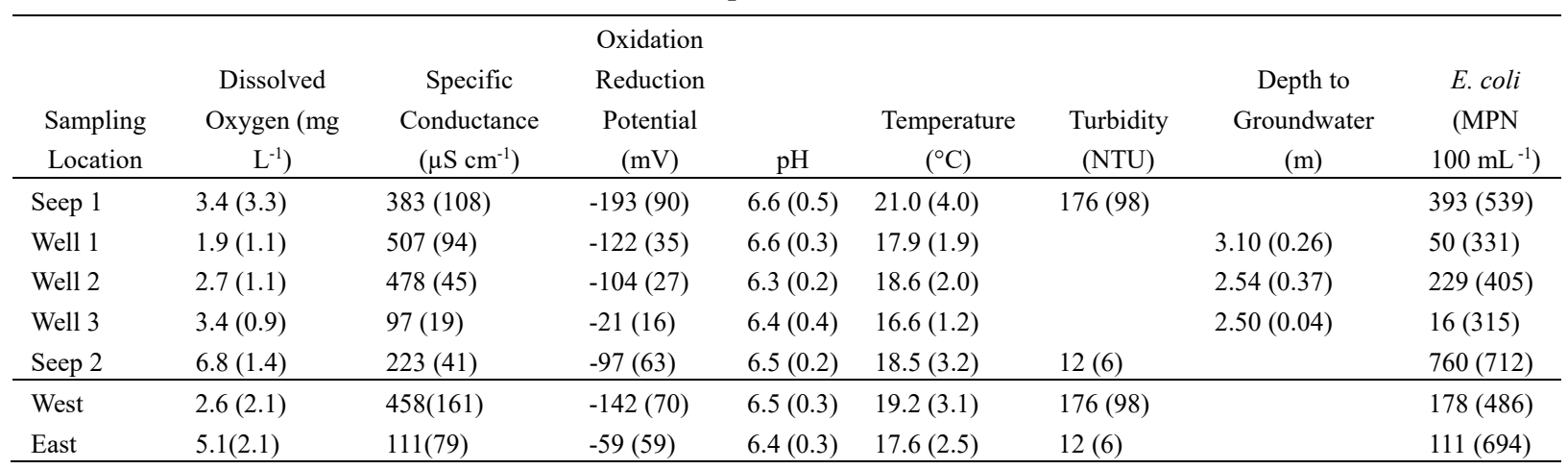




\subsection{Groundwater Biochemical Properties}

The mean dissolved oxygen concentrations were lower in Well $1\left(1.9 \pm 1.1 \mathrm{mg} \mathrm{L}^{-1}\right)$ and Well $2\left(2.7 \pm 1.1 \mathrm{mg} \mathrm{L}^{-1}\right)$ relative to Well $3\left(3.4 \pm 0.9 \mathrm{mg} \mathrm{L}^{-1}\right)$ and differences in dissolved oxygen concentrations between groundwater from wells on the west and east sides were significant $(p=0.008)$ (Table 2). Prior research has shown that dissolved oxygen concentrations and oxidation reduction potential of groundwater both decrease in the presence of benzene compounds (Takahata et al., 2006) and benzene was detected in groundwater samples on the west side of TC. The specific conductance and turbidity of water was significantly $(p<0.05)$ greater near Seep 1 (383 $\left.\pm 108 \mu \mathrm{S} \mathrm{cm}^{-1} ; 176 \pm 98 \mathrm{NTU}\right)$ in comparison to Seep $2\left(223 \pm 41 \mu \mathrm{S} \mathrm{cm}^{-1} ; 12.0 \pm 6 \mathrm{NTU}\right)$ (Table 2). Well 1 and Well 2, which are located on the west side of TC also had higher specific conductance $\left(507 \pm 94 \mu \mathrm{S} \mathrm{cm}^{-1}\right.$ and $\left.478 \pm 45 \mu \mathrm{S} \mathrm{cm}^{-1}\right)$ in comparison to Well $3\left(97 \pm 19 \mu \mathrm{S} \mathrm{cm}^{-1}\right)$ on the east side (Table 1). Groundwater specific conductance can be influenced (increase) by the biodegradation of fuel products (Bermejo et al., 1997; Werkema Jr. et al., 2003). Soil microorganisms lower the redox potential of groundwater when a contaminant plume is oxidized, and electron acceptors such as oxygen, nitrate, and iron $\left(\mathrm{Fe}^{3+}\right)$ are depleted (Takahata et al. 2006; Gomez et al. 2009). The concentration of reduced iron $\left(\mathrm{Fe}^{2+}\right)$ in groundwater may increase where biodegradation occurs (Takahata et al., 2006). When groundwater enriched with $\mathrm{Fe}^{2+}$ encounters aerobic environments such as streambeds, microbial oxidation occurs, imparting an orange or red color to the water (Van der Grift et al., 2014) and increasing the turbidity. This was observed near Seep 1 (mean turbidity $=176$ NTU), but not Seep 2 (mean turbidity $=12$ NTU) (Table 1). Strong fuel odors were present in all water samples collected from Seep 1 and Well 2 but not from Seep 2 or Well 3. All of the leaking UST on the west side of TC have been "closed out" (Figure 1), however groundwater on the west side of TC still contains benzene and data suggests fuel products continue to influence the physical and chemical properties of water, soil, and air quality.

\section{Conclusion}

The project goal was to determine if the drainage from TC posed threats to public and environmental health. Concentrations of E. coli in TC exceeded the US EPA (1986) suggested threshold $45 \%$ of the times sampled during baseflow conditions and $80 \%$ of times sampled during stormflow. Prior studies have also documented elevated bacteria concentrations in urban streams during storms relative to baseflow. This research has shown that bacteria concentrations in groundwater and at the groundwater/surface water interface (Seeps) may also be elevated relative to recommended standards in coastal urban watersheds. When concentrations of $E$. coli exceed the recommended thresholds, people that recreate in the waters are more likely to contract water-borne illnesses (US EPA, 1986). The City of Greenville has acquired grant funds and low-interest loans to install stormwater control measures including a regenerative stormwater conveyance, bio-retention cells, and stormwater wetlands in the watershed. These practices should help improve water quality by treating and reducing urban runoff (Humphrey et al., 2014). Pet waste collection stations are also suggested to reduce pet contributions of $E$. coli to shallow groundwater and surface waters.

Water samples collected from Seep 1 along the western bank of TC had benzene concentrations that exceeded the standard $50 \%$ of times sampled during the study period, and $50 \%$ of times sampled over the past decade. Soil sampled from Seep 1 emitted benzene concentrations in the air that exceeded short-term exposure levels $75 \%$ of the times sampled. Furthermore, strong benzene odors were present near and down-wind from Seep 1 on every field visit $(\mathrm{n}=16)$. Benzene concentrations in groundwater discharge from Seep 1 will likely be diluted by TC and the Tar River, thus lowering exposure risks from direct contact with recreational waters. However, data suggest that exposure risks via inhalation of the known carcinogen benzene (from contaminated soil) at concentrations that exceed short term thresholds may be high for people that recreate or work in the area. These data show that the legacy effects of the leaking UST persist and pose real threats to environmental health near TC despite past groundwater remediation efforts and the site being listed as "low-priority". There are more than 9,500 other sites in NC and over 450,000 across the US with documented contamination from UST that have been remediated and "closed out" like TC (US EPA, 2011). These other sites may also pose threats to environmental health if air quality was not considered during the threat assessment and ranking process. East Carolina University has received grant funding to plant riparian vegetation adjacent to TC to help reduce bank erosion and stimulate phytoremediation of groundwater pollutants. Mitigation and monitoring of these threats from UST and urban runoff is expensive but vital to protecting environmental health. This study was conducted in TC, but many other watersheds in the state, country, and world face similar water quality issues associate with urbanization and groundwater, surface water, and air pollution. 


\section{Acknowledgments}

The authors would like to acknowledge the efforts of Caitlin Skibiel, Jeremy Robbins, and Mark Akland for their help with field and lab work.

\section{References}

Abou-Shanab, R. A., Eraky, M., Haddad, A. M., Abdel-Gaffar, A. R. B., \& Salem, A. M. (2016). Characterization of crude oil degrading bacteria isolated from contaminated soils surrounding gas stations. Bulletin of Environmental Contamination and Toxicology, 97(5), 684-688.

Agency for Toxic Substances and Diseases Registry. (ATSDR) 2016. Toxic substances portal- Benzene. Retrieved May 16, 2016 from http://www.atsdr.cdc.gov/MMG/MMG.asp?id=35\&tid=14

Ahmed, W., Neller, R., \& Katouli, M. (2006). Population similarity of enterococci and Escherichia coli in surface waters: A predictive tool to trace the sources of fecal contamination. Journal of Water and Health, 4(3), 347-356.

Bermejo, J. L., Sauck, W. A., \& Atekwana, E. A. (1997) Geophysical discovery of a new LNAPL plume at the former Wurtsmith AFB, Oscoda, Michigan. Ground Water Monitoring and Remediation, 17(4), $131-137$.

Calza, A., Bataglia, V., Benassi, R. F., \& Mata-Lima, H. (2015) Soil and Groundwater Contamination with Benzene: A Case Study of a Petrol Station in an Urban Area. Environmental Quality Management, 25, 93-104

Gallegos, P., Lutz, J., Markwiese, J., Ryti, R., \& Mirenda, R. (2007) Wildlife Ecological Screening Levels for Inhalation of Volatile Organic Chemicals. Environmental Toxicology and Chemistry, 26(6), 1299-1303.

Gomez, D., \& Alvarez, P. (2009) Modeling the Natural Attenuation of Benzene in Groundwater Impacted By Ethanol-Blended Fuels: Effect of Ethanol Content on the Lifespan and Maximum Length of Benzene Plumes. Water Resources Research., 45, W03409. https://doi.org/10.1029/2008WR007159

Haest, P. J., Lookman, R., Van Keer, I., Patyn, J., Bronders, J., Joris, M., Bellon, J., \& De Smedt, F. (2010) Containment of Groundwater Pollution (Methyl Tertiary Butyl Ether and Benzene) to Protect a Drinking-Water Production Site in Belgium. Hydrogeology Journal, 18, 1917-1925.

Harwood V. J., Whitlock, J., \& Withington, V. (2000). Classification of Antibiotic Resistance Patterns of Indicator Bacteria by Discriminant Analysis: Use in Predicting the Source of Fecal Contamination in Subtropical Waters. Appl. Environ. Microbiol., 66(9), 3698-3704.

Hathaway J.M., W.F. Hunt, and O.D. Simmons III. (2010). Statistical Evaluation of Factors Affecting Indicator Bacteria in Urban Storm-water Runoff. J. Environ. Eng., 136(12), 1360-1368.

Humphrey, C., Chaplinski, N., O’Driscoll, M., Kelley, T., \& Richards, S. (2014). Nutrient and E. coli Attenuation in a Constructed Stormwater Wetland in the North Carolina Coastal Plain. Environment and Natural Resources Research, 4(3), 12-22. https://doi.org/10.5539/enrr.v4n3p12

Humphrey, C., Finley, A.J., Iverson, G., Manda, A., \& O’Driscoll, M. (2015). Groundwater and stream E. coli concentrations in coastal plain watersheds served by onsite wastewater and a municipal sewer treatment system. Water Science and Technology, 72(10), 1851-1860.

Iverson, G., Humphrey, C., Postma, M. H., O’Driscoll, M. A., Manda, A. K., \& Finley, A. (2017). Influence of sewered versus septic systems on watershed exports of E. coli. Water Air \& Soil Pollution, $228,237$. https://doi.org/10.1007/s11270-017-3426-1

Mallin, M., Williams, K. E., Esham, C., \& Lowe, R. P. (2000). Effects of Human Development on Bacteriological Water Quality in Coastal Watersheds. Ecological Applications., 10(4), 1047-1056.

Meszaros, N., Subedi, B., Stamets, T., \& Shifa, N. (2017). Assessment of Surface Water Contamination from Coalbed Methane Fracturing-Derived Volatile Contaminants in Sullivan County, Indiana, USA. Bull Environ Contam Toxicol., 99, 385-390.

North Carolina Department of Environmental and Natural Resources. (2007). Division of Water Quality "Redbook". Surface Water and Wetland Standards. NC Administrative Code 15A NCAC 02B.0100,.0200 \&.0300

North Carolina Department of Environmental Quality. (2017). Division of Waste Management. Waste Management GIS Data and Maps https://deq.nc.gov/about/divisions/waste-management/waste-management -rules-data/waste-management-gis-maps 
S\&ME., Inc. (2011). Surface Water Sampling Report: Town Creek Downtown Greenville. North Carolina Department of Environment and Natural Resources.

Smith Jr, J. E., \& Perdek, J. M. (2004). Assessment and Management of Watershed Microbial Contaminants. Critical Reviews in Environmental Science and Technology, 34(2), 109-139.

Takahata, Y., Kasai, Y., Hoak, I. T., \& Watanabe, K. (2006). Rapid Intrinsic Biodegradation of Benzene, Toluene, and Xylenes at the Boundary of a Gasoline-Contaminated Plume Under Natural Attenuation. Appl Microbiol Biotechnol, 73, 713-722.

United States Center for Disease Control and Prevention. (2017a). Recreational Water Illnesses. CDC. Retrieved from https://www.cdc.gov/healthywater/swimming/swimmers/rwi.html

United States Center for Disease Control and Prevention. (2017b). Emergency Preparedness and Response: Benzene. Retrieved from https://emergency.cdc.gov/agent/benzene/basics/facts.asp

United States Climate Data. (2017). Climate Greenville-North Carolina. Retrieved from https://www.usclimatedata.com/climate/greenville/north-carolina/united-states/usnc0281/2016/1

United States Environmental Protection Agency. (1986). Ambient Water Quality Criteria for Bacteria. EPA440/5-84-002.

United States Environmental Protection Agency. (2011). State Summary Chapter: North Carolina. The National LUST Cleanup Backlog: A Study of Opportunities. Retrieved from https://www.epa.gov/ust/ national-lust-cleanup-backlog-study-opportunities

United States Environmental Protection Agency. (2017). National Primary Drinking Water Regulations. Retrieved from https://www.epa.gov/ground-water-and-drinking-water/national-primary-drinking-water -regulations

Van der Grift, B., Rozemeijer, J. C., Griffioen, J., \& Van der Velde, Y. (2014). Iron Oxidation Kinetics and Phosphate Immobilization Along the Flow-Path from Groundwater into Surface Water. Hydrol. Earth Syst. Sci., 18, 4687-4702.

Werkema Jr., D.D., Atekwana. E.A., Endres, A.L., \& Sauck, W.A., Cassidy, D.P. (2003). Investigating the Geoelectrical Response of Hydrocarbon Contamination Undergoing Biodegradation. Geophysical Research Letters, 30(12), 1647-1649.

Whitlock, J.E., Jones, D.T. \& Harwood, V.J. (2002). Identification of the Sources of Fecal Coliforms in an Urban Watershed Using Antibiotic Resistance Analysis. Water Research, 36, 4273-4282.

World Health Organization. (2017). Drinking-water Fact Sheet. WHO. Retrieved from http://www.who.int/ mediacentre/factsheets/fs391/en/

Wright M.E., H.M. Solo-Gabriele, S. Elmir, and L. E. Fleming. (2009). Microbial load from animal feces at a recreational beach. Mar. Pollut. Bull., 58, 1649-1656.

Yang, Q., Li, Y., Zhou, J., Xie, X., Su, Y., Gu, Q., \& Kamon, M. (2013). Modelling of Benzene Distribution in the Subsurface of an Abandoned Gas Plant Site After a Long Term of Groundwater Table Fluctuation. Hydrological Processes, 27, 3217-3226.

\section{Copyrights}

Copyright for this article is retained by the author(s), with first publication rights granted to the journal.

This is an open-access article distributed under the terms and conditions of the Creative Commons Attribution license (http://creativecommons.org/licenses/by/4.0/). 